\title{
ANALYSIS AND EVALUATION OF DIFFERENT APPROACHES TO DETERMINE QUALITY COSTS ${ }^{1}$
}

\section{Yrd. Doç. Dr. Caner CEBECİ}

\begin{abstract}
Quality cost considerations have long been an issue in the literature of quality management. The debate about the meaning and manner of collection of quality costs continues to this day. To make such a process more efficient and meaningful, it is first necessary to identify the quality of accumulated cost. The aim of this paper is to explain and demonstrate a number of quality cost evaluation methods. Also an analysis is made herein of certain options that can be used to calculate the cost of quality and what steps should be taken to ensure that reliable quality costing is achieved. Only the conceptual frameworks of quality management models are presented in this work.
\end{abstract}

Keywords: Quality Cost, Quality Management, Failure Cost

Jel Classification: D24, L11, M22

\section{KALITE MALIYETLERINIIN TESPITİ İÇIN KULLANILAN FARKLI YAKLAŞIMLARIN ANALIZZi VE DEĞERLENDİRILMESİ}

ÖZ

Kalite maliyetleri ile ilgili değerlendirmeler uzun süredir kalite yönetimi literatüründe bir konu olmaya devam etmiştir. Kalite maliyetlerinin anlamı ve yöntemiyle ilgili tartısmalar bugün de devam etmektedir. Bu süreci daha verimli ve anlaml hale getirmek için, ilk önce toplam kalite maliyetini belirlemek gereklidir. Bu yazının amacı çok sayıda kalite maliyet değerlendirme yöntemlerini açıklamak ve göstermektir. Ayrıca kalite maliyetlerini güvenilir bir şekilde hesaplamak için kullanılan ve hangi adımlarla bunların elde edileceğini gösteren bazı analizlerde yapılmıştır. Bu çalışmada kalite yönetim modelleri sadece kavramsal çerçevede sunulmaktadır.

Anahtar Kelimeler: Kalite Maliyeti, Kalite Yönetimi, Hata Maliyeti

Jel Sinıflandirmasi: D24, L11, M22

\footnotetext{
${ }^{1}$ This study was prepared by extending the paper of "The Challenge of Measuring and Managing the Cost of Quality" which was presented in $15^{\text {th }}$ IAMB Conference in Lisbon in April 2013.

* Melikşah Üniversitesi, İ.İ.B.F., İşletme Bölümü, ccebeci@meliksah.edu.tr
} 


\section{INTRODUCTION}

In response to ever shorter innovation cycles, many companies strive to improve the quality of their products and services. Often, this is done through actions that are characterized as components of a quality management system. As a result, quality cost considerations have long been an issue under consideration in quality management literature. The debate about the meaning and manner of quality cost collection continues to this day. It is of great importance that the process parties recognize the meaning and purpose of quality costing. Such an understanding can serve as a template for further cost saving programs and it should also provide an indication as to how weaknesses in the process can be rectified more effectively by the elimination of defects in the process. To achieve this, various types of cost analysis must be identified and scrutinized to ascertain and establish the efficiency of a process.

To achieve a reduction of these deficiencies in the process of quality costing, it is necessary to identify the quality costs incurred. The aim of this paper is to explain and demonstrate a number of quality cost evaluation methods. An analysis is also made herein of certain options that can be used to calculate the cost of quality and what steps need to be taken to ensure that reliable quality costing is achieved. In particular, an analysis is made to determine which other costs should also be included when one considers the cost of quality in addition to the costs already identified in the available literature and what measures must be taken to ensure reliable quality costing.

In other words, in this work it is intended to carry out a detailed analysis on the cost of quality. Initially, only quality management models can be used to assist in this analysis. It is also important to recognize from the outset that an economic depression would enable the scope of this work to be extended further.

There are controversial discussions conducted on quality costs in literature. Excerpts of these discussions are included to make it clear that in order to determine quality costs, a clear path must be defined. This is the responsibility of leadership. One must choose a course of action and sensitize employees to the issue of quality costs. Otherwise employee resistance to such issues may arise and spread throughout the workforce and, as a result, expected potential savings would not be achieved.

\section{QUALITY COSTS}

If you search for a definition of the concept of quality costs, you will discover a variety of different concepts to find their distribution and analysis. It is clear that currently there is no uniform scientific theoretical or -practical approach of defining or analyzing this concept in existence. In practice, one often finds a classic tripartite divisional split definition namely: the cost of quality in prevention costs, appraisal costs and failure costs (DGQ,1985). Other concepts directly criticize this approach and leave out the cost of testing and prevention costs from quality cost analysis. They thus cover only those costs actually incurred by failures, e.g. caused in the production (SAQ, 1985). 
The following section presents the different approaches to the analysis of quality costs. Here the discussion centres on, firstly, various definitions and partly diverging conceptual uses and boundaries in literature and how they are used in practice. Then, secondly, a comparison is made of the classical and the modern approaches to the classification and quantification of quality costs and these represent the two basic approaches. From this basic analytical survey of the possibilities of process costing one can then begin to construct a cost-based quality management system. The aim in this part of the work is to demonstrate an overview of developments in the field of quality cost collection and calculation.

\subsection{Divergent Quality Cost Definitions and Concepts in the Literature}

The concept of quality costs is not without controversy in the literature. While some definitions are very strongly technically oriented and do not pursue a holistic approach, some authors reject the term quality cost altogether on the basis that it inherently creates a suggestion of a relationship between cost and quality (Herberg, 2000:189).

Some authors advocate the quality costs as a „non-quality costs“ (Brunner, 1988:41-44), as „failure costs“ (Bär, 1985), or in the English literature as „Poor Quality Costs“ (Harrington, 1987:6) or as „Inequality Costs“ (Groocock, 1986:53).One Criticism of the concept of quality cost is that it is argued that it can give the misguided impression that better quality can only be realized by higher costs. Actually, the opposite is true as the so-called quality cost concept arose solely due to the failure of keeping costs down. Further, such a simplistic approach would suggest failure -free production is always attainable which is never the case (Bär, 1985:494).

Another criticism concerns the impression held that a two-fold decrease in value would affect both the production as well as the quality of the product (Spitzner, 1988:1021-1029). It has therefore been recommended that instead of using the term, 'quality cost' it would be more accurate to use 'quality-related costs' in conceptual discussions. (DIFN, 1995; Steinbach, 1994).

The problem is that the term 'quality cost' can be too objective and is contradictory when cost categories are combined - on the one hand a certain quality of investment is needed to ensure the precise and desired quality (prevention costs and part of the costs of testing). However on the other hand, the negative effects of insufficient quality (internal and external failure costs) - cannot be solved by simply redefining 'quality costs' to 'quality-related costs' (Sasse, 2002:96)

It is also argued that usage of the term 'quality costs' is flawed when one considers „,...) in particular the failure prevention and control costs from the actual saving potentials, the failures as well as the wastes (...)“ (Tomys, 1994:38). The focus of a cost analysis for quality therefore should be on discussing the question does the failure-free argument stand up to scrutiny (Kamiske, 1992:122). If only failure costs are to be taken into account, then it is argued that economic optimization of the quality management measures cannot be reached, since only part of the quality-related cost-related consequences would be made visible (Sasse, 2002:97). The possibility of the determination of a 
package in terms of cost-effective measures to prevent failures would be hidden in a restriction on the failure costs terminology from the outset. Above all obscurity would be created by focusing on failure cost as being the sole causal link between the failures occurring and their costs (failure costs) without consideration of the measures of failure prevention and test analysis because failure costs can be affected by measures of failure prevention and testing.

A sole assessment of failure costs cannot uncover the relationships between measures of failure prevention, quality control and the occurrence of failures. Accordingly, it is necessary to determine the efficiency of quality management to detect failure and failure-related costs, moderate success and the consequences of failure prevention and appraisal costs (Sasse, 2002:97).

It is clear that there are two main approaches defining the development of the concept of quality costs. Firstly the one that Masser introduced in 1957 namely the triple division of quality costs: prevention costs, appraisal costs and failure costs (Masser, 1957:37; Aniza et al., 2013:738). This division has also been known as the „classic quality cost-concept” and was adopted also by the German Society for Quality (DGQ) 1985.

The second attempt in reaching a definition is based on the division of the costs and was spawned in 1981 by Hahner. This definition distinguishes between basic quality cost and quality extra cost. It differentiates between what Hahner refers to as' basic costs' such as the costs incurred for the creation of quality and „additional costs” of poor quality (Hahner, 1981:12,15). Thus, as a result, Wildemann used the definition of Hahner, to introduce the terms „,cost of conformance” and „cost of non-conformance” (Wildemann, 1992:765). The German Institute for Standardization (DIFN) and DGQ have adopted this definition in recent years instead of the classic threefold definition in their respective standards (DIFN, 1992; DGQ, 2000).

The first classic quality cost concept analyzed below. The analysis also covers discussions on some of the criticisms of this concept, as well as on the transition away from it to the division of Quality Costs. The concept of division of quality costs referred to in the literature as the „modern dichotomy" is elaborated on in detail in Section 2.3.

\subsection{The Classic Quality Cost Concept}

The classic quality cost structure is subdivided according to the main tasks of the Quality Department. The division of cost of quality is based on the development of a quality cost system by the U.S. Company General Electric in the 1950s. This quality cost system was developed because the U.S. Defense Department prior to awarding contracts reviewed quality assurance as well as all activities related to quality. Excessively high quality cost products concerned the company and contracts were not awarded to it in such cases. The company's objective in developing a quality cost system was to determine the necessary actions needed to be taken in order to meet the quality requirements and to discover any lack, or failure to cover, necessary products or processes. In order to 
achieve this objective, it utilized cost categories in conjunction with quality cost system data, which tallied the costs related to developing a quality system and inspecting products and processes applied, as well as the cost incurred when a product failed to meet requirements (Tomys, 1994).

Prevention costs were those costs which were expected to be incurred while applying quality management measures that serve to prevent and correct failures (DGQ, 2000:17). Steinbach on the other hand labeled the actions listed in the „prevention costs” as the „cost elements including quality planning and quality control costs" because the definition of prevention costs has a number of other costs which do not belong to the quality costs group and so they were grouped under this heading instead (Steinbach, 1994:23).

A similar view was taken by the American Society of Quality Control, which considered the costs for the planning and the implementation and maintenance of the quality system as ,prevention costs” (ASQC, 1971:75). „One example is the cost of purchasing new manufacturing machinery to improve production safety, i.e. investment costs in the area of production, which can be referred to, by definition as, prevention costs, but these costs are not attributable to the quality" (Steinbach, 1994:11). Any endeavour to identify prevention costs may result in the following two misinterpretations of the concept (Campanella, 1999:22):

- Certain parts of the test or failure costs associated with the activities concerning ,point-in-time failure" and incurred in avoiding higher failure costs may also be included in the components of prevention costs. Such costs are certainly not the prevention costs. In this context, only those costs which serve to avoid the occurrence of certain failures in the future, thereby reducing failure costs over the time, should be attributed to prevention costs .

- Certain parts of the „normal“ production costs (e.g. monitoring of measuring systems for production machines, proof reading a test report of an employee of the production etc.) could be attributed to the employee's character but they could also be attributed to the failure-prevention costs. Since these activities are an integral part of service provision, these cost factors should, however, be attributable to production and not prevention costs, and this is exactly how these cost factors are dealt with in practice.

Under the second category of costs, the costs of testing, the cost of activities, measures and facilities for identification of defective products or services are subsumed. „Appraisal costs are costs that are primarily caused by quality tests (...). They do not belong to the testing costs and other costs time work quantity findings and for sorting and retests for example, complaint about deliveries ", (DGQ, 1985). The term appraisal costs include all costs that are caused by routine detection; control and management of quality in the manufacturing process (DGQ, 1985). The findings control or controlling can use a full audit (Piece by piece inspections) or sampling tests can be made (DGQ, 1985). 
Failure costs are caused by products or processes which during the process of production do not meet the conditions laid down in the relevant drawings and specifications and quality requirements (DGQ, 1985). It has proved to be useful to divide the failure costs into two major groups, namely the internal and external failure costs (DGQ, 1985). Bruhn and Georgi specify the groups in detail as follows (Bruhn and Georgi, 1999:48):

- Internal failure costs result from the consequences of failures that occur before a customer has made contact with a seller. Examples of the causes of internal failure costs are the scrapping, reworking, re-testing or re-inspection of the materials used or the downgrading of faulty services.

- External failure costs are generated by the consequences of failures that occur only after contact between the customer and the provider and its performance. Exemplary sources of external failure costs are the complaints handling, guarantees, product liability payments, recoveries or product recalls or churn (Tsai et al., 2012; Aniza et al., 2013)

The basic idea of the classical quality cost concept is the idea that with the help of measures in the field of failure prevention, the number and scope of resulting internal and external failures can be reduced. This concept also assumes a close causal link between the fault prevention and control costs on the one hand and the internal and external faults on the other hand. This relationship is illustrated graphically in Figure 1 below.

Figure 1. The Older Model of Quality Costs Optimization

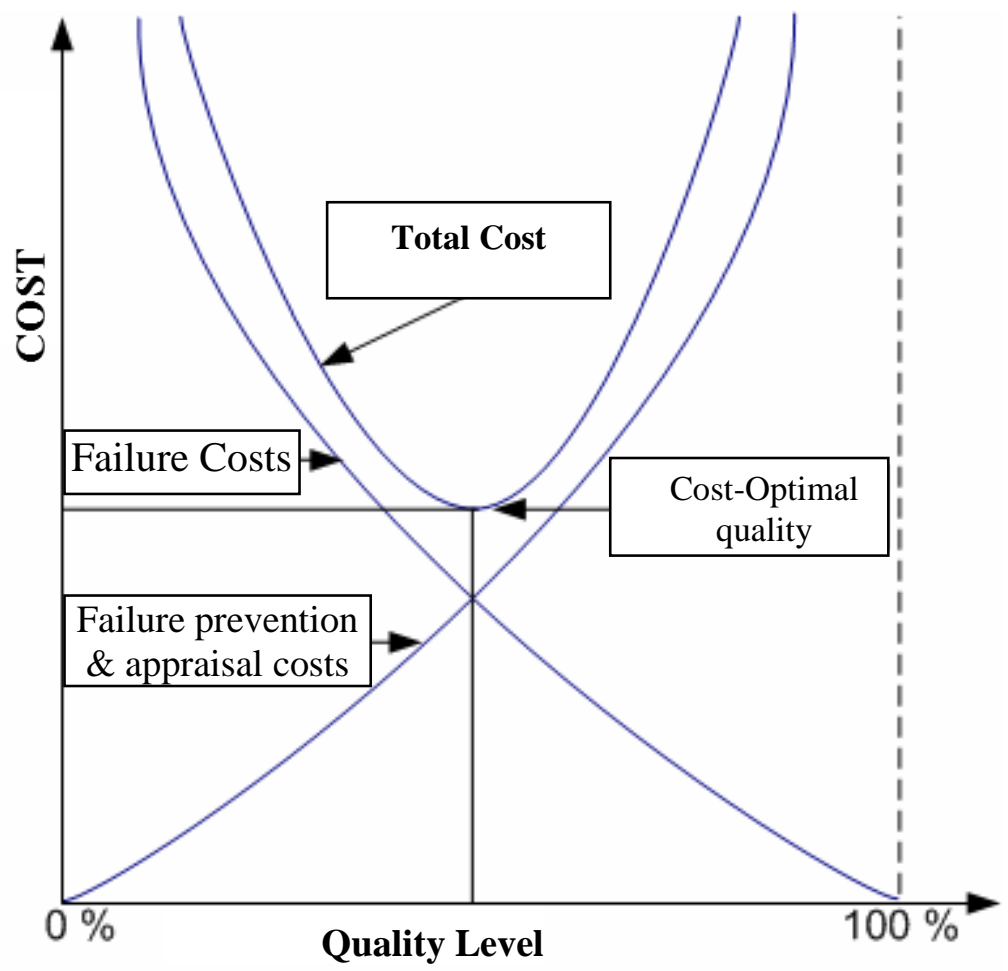

Source: (Grechenig et al., 2010: 470) 
In the symmetric model (same course of failure prevention curves and testing costs curves and failure cost curves) as shown in the above figure, the failure costs are reduced proportionally by increasing the cost of failure-prevention and testing. The total quality costs are increased from the mistakes of prevention and appraisal costs and the cost of failures. The amount of the failure cost can be controlled by the use of resources in the area of quality assurance and quality control measures (Bröckelmann, 1995:53). Complete accuracy of the production is only possible with an exponential increase in quality assurance measures.

On the other hand, exponential increase in the cost of failures is likely to occur when there is a complete retraction of tests and measures designed to prevent failure. The upshot of all these considerations is to assess the point at which the sum of the cost of quality is minimal (Bröckelmann, 1995:53).

The cost-optimal quality is shown in the model of the tripartite division at the point where the last unit of costs incurred for failure prevention and testing is higher than the unit costs saved by chance (Wilken, 1993:176).

\subsubsection{Criticism of the Traditional Tripartite division of Quality Costs}

With respect to the traditional approach of the tripartite division of the quality costs, the underlying understanding of achieving optimum quality costs has attracted some criticisms which are mentioned below:

- The first criticism relates to the formation of the quality cost elements. According to many authors listed in the DGQ, quality cost elements are an unstructured list of quality cost elements on different layers and phenomena and therefore a single classification criterion is essentially missing (Hahner, 1981; Fischer, 2000; Steinbach, 1994). For some, the cost of education-group testing costs is arbitrary because of a combination of individual cost elements, for example the cost incurred for quality audits and the cost incurred for sorting out faulty parts (Kandaouroff, 1994:769).

- In the testing costs there are different types of costs incurred in conducting tests (Entrance tests, manufacturing tests..) but there are also separate quality cost elements listed, such as the cost of testing equipment. This necessarily leads to problems in testing costs acquisition and allocation (Sasse, 2002:100).

- There is also a criticism that impairments are expected uncritically to be inherently internal failure-free (Steinbach, 1994:75). Impairments represent deductions, such as through the sale of products under the regular price (2. election) and although they do not incur additional costs, they are less redeemable. The reason for the recognition of impairment charges as being within a failure cost category is because impairments are undefined attributable costs unlike the 
scenario in corresponding cost centres (Sasse, 2002:101). For impairments to be included in the cost is open to criticism, since these impairments are not consumption goods - which is a constituent part of the underlying definition of cost .Instead they merely provide a reduction in revenue. Inadequate separation of other related variables such as value sales deductions or charges has also been criticized by commentators (Binner, 2000:9).

- Another criticism relates to the strong focus of quality cost elements on the production-related quality assurance (Bröckelmann, 1995:59). The reason for such criticism stems from the fact that the quality cost analysis was originally limited to the manufacturing sector. However as part of the total quality management concept, quality cost analysis has now been extended to quality management measures in other areas within and outside organizations (Harrington, 1987; Morse et al., 1987). The performance ranges provided in the classic threefold quality cost elements has not however been expanded in a similar way.

- In addition to the criticism of the listed quality cost elements there is also a criticism as to how determination of optimum quality costs is made under the traditional tripartite division of the cost of quality. (Sasse, 2002: 102). The reason for this is that the traditional understanding of quality costs is the assumption commonly expressed that the optimum cost of quality is at a level of quality that may tolerate a certain level of failure (Wildemann, 1992; Wonigeit, 1996). From fig. 2 it is evident that there must be a company objective to produce this cost-optimal level of quality, as an improvement in the failure rate would result in higher quality costs. It is assumed in this quality cost assessment that efforts are made to secure the optimum assessment to secure the product quality at minimum cost. To this end, according to Tomys (1994) : „(...) the best quality of the products should not be achieved at all cost because of the cost in mass production for delivery to buyer markets in the foreground". The cost-optimal quality is according to the classical approach, reached at a the point where the last unit costs incurred for failure prevention and testing is higher than the unit cost in saved failure.

- The classic commercial cost accounting does not include the quality cost as an independent cost. For this reason, quality costs in corporate accounting are recorded separately or not reported at all. Due to the lack of recording this independent cost assessing must be checked in each case. A proportion of quality costs assessment is made in the conventional cost-type cost centre and in cost unit accounting. This is a function- income-and piece-cost-related approach which according to the specifications of Taylorist organizational structures, in relation to the fault or the fault of the product cost are done at the centre. There is, however, no processoriented and quality-related quality circular acquisition cost assessment made. In order to be hierarchical internal or external customer and vendor interface problems should be ignored (Binner, 2000:9).

- The above definition of quality costs shows that quality costs are understood as an additional cost. Good quality means additional work and better quality causes more costs. There are 
positive investments to be made to improve quality mixed with negative expenditure troubleshooting.

- The final criticism of the classic threefold approach is that customer satisfaction aspects are scarcely noticed and in this context this omission is also apparent in a companies which have increasingly applied philosophy of Total Quality Management (TQM).

\subsubsection{Transition to the Use of A Modern Definition of Quality Costs}

The above critical examination of the traditional cost of quality classification may lead one to the conclusion that it has now become obsolete. Modern companies conscious preference change toward TQM with the attendant need for process orientation clearly shows the weaknesses of the traditional quality concept (Lim et al., 2013:3). This is characterized by the fact that it evaluates the risk of failures of products monetarily but not its quality or even its current market acceptance (Graf, 1998:41). Thus it is clear that computing systems based on this traditional tripartite division are solely designed to minimize manufacturing costs relating to quality. A customer-oriented and holistic approach is thus explicitly excluded (Wilken, 1993:156). In any such calculation, quality costs and the opportunity costs must be included. Defective products may cause decreased sales of a company . The decreased revenues of the future because of the bad experiences suffered by the customer in terms of product quality must be taken into account in the calculation of quality costs. An alternative classification of quality costs is needed, therefore, to remedy the deficiencies of the traditional tripartite division and to satisfy and take into account the current requirements of TQM and process orientation. It is also interesting to note that now even DGQ has deviated from this traditional tripartite division approach and this is evidenced in Sections 14-18 of its written dichotomy in conformance costs (costs of conformance) and performs failure costs (costs of non-conformance), which is presented in the next section DGQ (1985:26).

\subsection{Modern Approach: Dichotomy of Quality Costs}

As a result of the problems associated with and the criticisms made against the tripartite division of cost of quality, and the development in the 1980s concerning the division of the cost of quality a different approach was suggested by, inter alia, Crosby (1986:92).

Crosby made a differentiation in quality costs between the cost of non-conformance requirements and the cost of compliance with requirements (Crosby, 1986:92-100). The cost of conformance requirements relates to measures to be necessarily taken to avoid mistakes and failure risk (Crosby, 1986; Wildemann, 1997; Wildemann, 1995)The cost of non-conformance requirements, however include the costs that are caused by failures and their correction (Crosby, 1986:92). Figure 2. illustrates the difference between the function-oriented view of classical quality costing (trisection) and the process-oriented view of modern quality-based cost accounting (Division). 
The function-oriented perspective of the classic threefold curve gives the optimum of quality costs in the course of failure cost curve and failure prevention and appraisal costs. As it has already been shown, this is at a cost-optimal quality grade of less than $100 \%$ (fig. 2). The process-oriented approach yields the optimal quality-related costs from the costs of conformance and the cost of the non-conformance. The modern approach to the division of quality costs is based on a different way of thinking than the traditional tripartite division. The division is based on the view that: „Quality does not cost anything. It is not given but it costs nothing. What costs money, however, is the lack of quality (...) (Crosby, 1986:1). Compared with the traditional view, the optimal cost (minimum cost) quality level in the modern approach is the division adopted with (for both technical and economic reasons ) almost one hundred percent conformance with the requirements (Bröckelmann, 1995; Danzer, 1990; Wildemann, 1992).

The division of the cost of quality has been adopted over the years by numerous authors expressing similar view points that there are considerations that should be taken into account in cost coincidence as well as (Wildemann, 1992; Fischer, 2000; Kandaouroff, 1994), non-conformance costs and conformance costs (Brunner, 1991) or from non-value added costs and value added costs (Seghezzi and Fries, 1995) .

Figure 2. Comparison of Current and Traditional Approach of Quality and Cost-Sharing
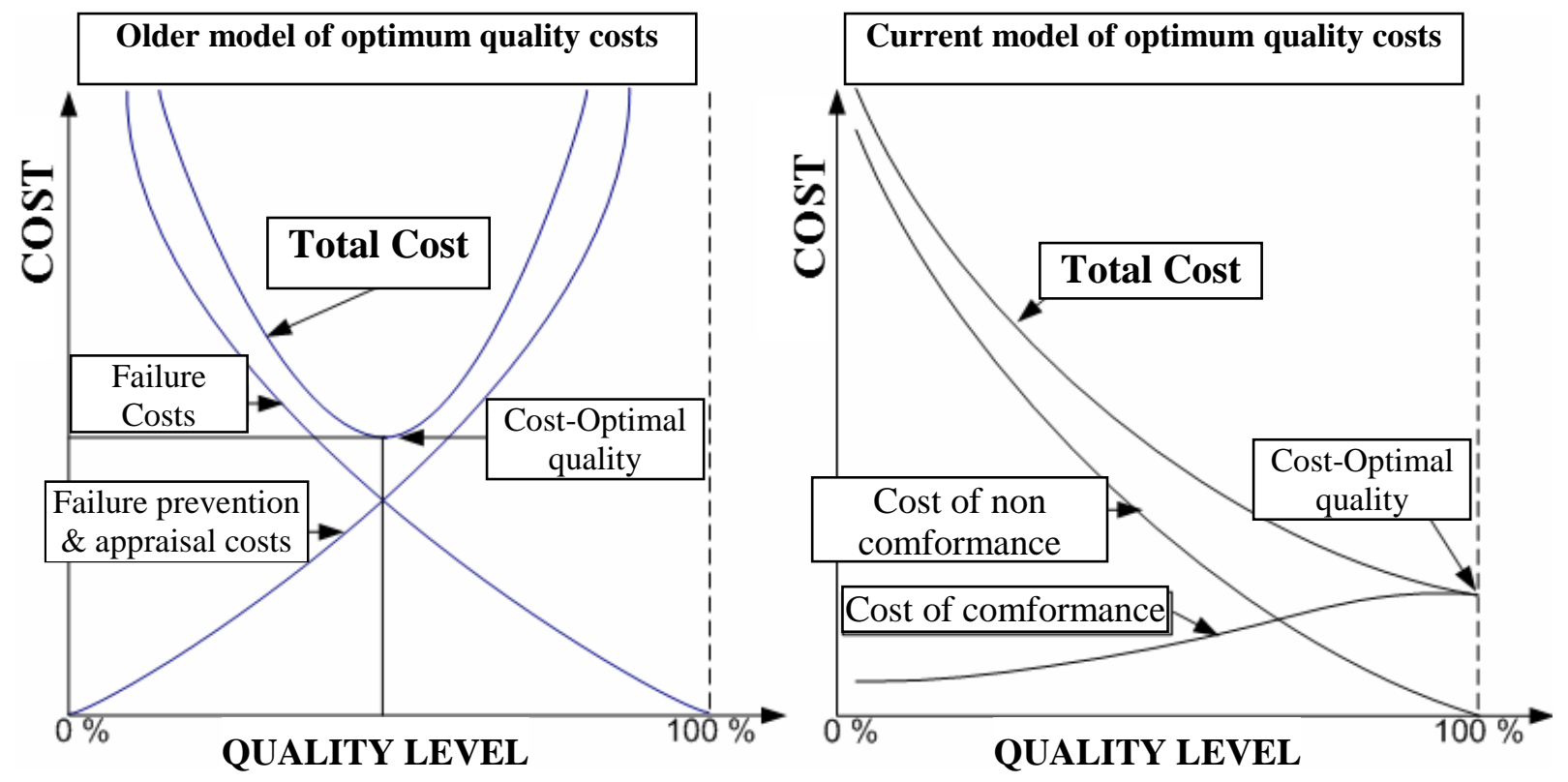

Source: (Wood, 2013: 9,10)

In further experiments, it is mentioned because of the variety of application examples in the literature relating to the cost of conformance costs and non-conformance costs. The transition from the classical tripartite division of the cost of quality prevention costs, testing costs and failure costs to the „new cost structure“ where there is a division of Quality Costs and where within that division 
there is difference between the cost of the conformance and cost of the non-conformance is illustrated in figure 2 .

It is clearly shown that the costs of conformance are composed of the cost of failure prevention and are treated as a concepts separate from the testing costs. The cost of non-conformance is composed of internal and external failure costs and certain items of inspection costs. The following Table 1. summarizes the characteristics of the two groups of costs, which will be discussed in more detail below.

Table 1. Overview of Cost of Conformance and Cost of Non-Conformance

\begin{tabular}{|l|}
\multicolumn{1}{|c|}{ Cost of Conformance } \\
\hline $\begin{array}{l}\text { costs incurred to the company to provide the ability } \\
\text { to produce and obtain faultless products }\end{array}$ \\
\hline Failure prevention and planned appraisal costs \\
\hline Positive share of value added \\
\hline Known, predictable, unavoidable \\
\hline
\end{tabular}

Cost of non-conformance

Costs incurred due to a lack of compliance with the performance requirements

Internal/External Failure costs, unplanned appraisal costs

Reduction of value added

only to be estimated, not planned, avoidable

\subsubsection{Cost of Conformance}

The cost of conformance, which has significant overheads influence, including costs incurred to meet the requirements and to ensure that it operates correctly, e.g. preventive measures for quality or training, are defined as costs incurred to the company to provide the ability to produce defect-free products (Binner, 2000:9) and thus it has an inherent investment characteristic. The cost of conformance includes, the prevention costs and the planned testing costs (Binner, 2000:10). Wildemann however differs in his approach on the cost of conformance tripartite split definition and prefers the use of the following terminology (1995:93):

- Cost of test and monitoring activities

- Cost of applying the techniques of quality management

- Techniques for quality-related training and education

Fischer added further to the cost of conformance by additionally taking into account qualityrelated suppliers and customer-related expenses and through this innovation he has introduced the growing importance of value networks that need to be taken into account (Fischer, 2000). The costs of conformance understood in terms of investment represents a positive contribution to value creation. They are generally given overheads characteristics and should be seen as investments in the future for the security and competitiveness of the company. The costs of conformance are known; predictable and unavoidable (Binner, 2000). The following table provides an illustrative overview of cost elements that belong to the group of matching costs: 
Table 2. Examples of Cost Elements in The Cost of Conformance

\begin{tabular}{|l|l|}
\hline Prevention Costs & Appraisal Costs \\
\hline Quality Functions Plan Costs & Inspection costs \\
Management of quality control & Product Testing costs \\
Quality-related training & Initial Samples Test \\
Quality Audit & Release test \\
Implementation of FMEAs & Test equipment \\
\hline
\end{tabular}

Source: (Wood, 2013: 185, Shukla; Agrawal, 2012: 1298)

\subsubsection{Cost of Non-Conformance}

The cost of non-conformance are costs, which are triggered by failure as well as their correction (Crosby, 1986). The costs of non-conformance include avoidable costs of inefficiency, waste, and failure costs of any kind (Binner, 2000). You can describe them as part of the factor inputs, beyond the power of creation and it is used as a necessary factor caused by the lack of conformity with the requirements of generated power (Wildemann, 1997). Non-conformance costs can thus be presented as an avoidable waste of resources and thus triggering a reduction of value (Binner, 2000). Non-conformance costs are by their very nature direct costs that are clearly attributable to the product (Tomys, 1994). The cost of the non-conformance can be avoided and this can be planned and estimated (Binner, 2000). The area of cost variance can be made analogous to the classic threefold divisions where internal and external non-conformance costs are made. The following table lists examples of some elements of the non-conformance costs:

Table 3. Examples of Cost Elements in The Cost of Non-Conformance

\begin{tabular}{|l|l|}
\hline Internal Failure Costs & External Failure Costs \\
\hline Rework & Guarantee and warranty \\
Unplanned testing & Product liability \\
Quantity variance & Product Recall \\
Problem investigation & Lost market share \\
Quality related downtime & Lost margins \\
\hline
\end{tabular}

Source: (Shukla; Agrawal, 2012: 1298)

\subsection{Collection of Quality Costs by the Quality of Cost Accounting}

Many authors write quality accounting for economies to function not as a separate cost accounting system but instead postulate the use of quality cost accounting as a special account (Graf, 1998:59) or as accessory charges (Hahner, 1981; Walluch, 1980).

A side account makes use of the quality of the accounting data from the operating cost calculation to determine the portion of the cost and quality information made available through the 
usage of various criteria. The purpose of this source of information must be to determine the proportion of quality costs compared to the total costs and to demonstrate the quality cost elements and its origins and causes (Horvath and Urban, 1991:117).

Any endeavor to defining the requirements for the collection of quality costs first needs required to limit the purposes of such a cost accounting system. This is necessary because quality costing is limited to the Quality Management System which is designed only for the purpose of mapping out a part of the operational management system. Traditional cost accounting systems cannot generally provide such information because their purpose is not oriented to quality concerns and although they can capture deterministic quality data for this purpose, they are not explicitly reported (Horvath and Urban, 1991:117). Comprehensive quality cost accounting systems are used for the following reasons and can produce the following data (Graf, 1998:57):

- Figures of quality costs, the teleological understanding of quality corresponding to and thus reflecting the market orientation of cost accounting

- Economical provision of information to support tactical / operational decisions in quality control

- Talking points to enforce quality measures and strengthening the function of quality control of the company

- Decision support for the development of new or improved quality standards

- Cost-effective control of quality determinative processes and detection of rationalization potentials

- Calculation of quality costs incurred to satisfy quality dimensions

If these requirements are considered in a quality cost accounting system, provision can be made for the analysis of quality costs based on calculations for a partial costs plan because only these kind of the costs accounts enable systematic debiting and control (Graf, 1998:58). In recent years, concern has emerged over doubts about the suitability of planned cost calculations on a part cost basis particularly because of the changed cost structures of companies and their information needs. Here it is argued that this kind of overall cost accounting (full cost accounting) should become increasingly dominant in the field of fixed and common costs or not at all or only partially (Partial cost accounting) (Graf, 1998; Reckenfelderbäumer, 1994).

\subsubsection{The Activity-Based Costing as The Basis of Quality-Related Decisions}

As a result of the many doubts about the adequacy of the existing accounting systems to measure quality costs base cost accounting has been developed. This allows source-related provision of information for quality-related decisions.

Substantially different process costing systems are now being used instead of traditional cost 
accounting systems which are using direct reference values (benchmarks). These reference values correspond to the so-called cost drivers. Under a cost driver, the factors are understood to have the greatest impact on the cost of a process. A process may, for example, have to produce a product or provide a service for destination purposes. Basically, the company's product is seen in the activitybased costing as the sum of many processes or activities, and the costs and benefits can be attributed to direct benchmarks. This results in activity-based costing, the cost of a product (or a performance) and the sum of the costs of all processes that have emerged for the production of the commodity (Kamiske and Brauer, 2003:199).

The tasks of the process costing include planning, management and control of overheads and the value-based mapping of resource consumption in the cost accounting for the purpose of providing information (Reckenfelderbäumer, 1994:26-30). The main objective of the activity-based costing here is to: increase the cost transparency in indirect activity areas, improve the product costing, to ensure the cause-appropriate allocation of overheads and to detect potential for efficient use of resources (Horvath, 1997:337).

While traditional cost accounting systems limit the control of efficiency of individual deferred cost centres, the basic principles of activity-based costing are based on the cost of interdepartmental considerations. This approach provides a cost-base analogous to the concept of value chain thinking. The cost of interdepartmental consideration of value-based operational service consumption also allows differentiation between value-added and non-value added processes. Despite the difficulties, in practice distinguishing between the two types of processes has the guarantee of accurate and detailed process costing and approximate knowledge of the amount of unwanted non-value-added processes which is of great importance (Graf, 1998:98).

\subsubsection{Recognition of a Cost-Based Quality Management System}

Kamiske and Tomys also gave much consideration to this process (1992:122 and 1994:30). However they first organized costing into individual processes and then evaluated them by giving due consideration to the effect on customer needs. Value-increasing processes are specifically referred to as being the best way of enhancing customer value or aspirational nature. Value-reducing processes are spending both money and time and can cause a company to suffer loss of reputation and loss of capacity due to reworking requirements.

A Clear and differentiated subdivision of processes has been tested by Kamiske and Tomys. They divide four categories of benefits : net power, performance piece, reactive power and blunder. Services rendered under all planned processes are understood which will increase the value of the product and thus contribute to an increase in benefit for the customer. The sum of all services rendered within the ideal value chain has the finished product linked to the output result.

Support services are also planned and their input of achievements increase the value of the 
product. They are also used for process support. As an example of this, intermediate inspections in production of an automobile manufacturer will be counted in this activity.

Reactive powers are unplanned processes such as intermediate storage and there is no cost element here so it has no positive effect on the product. Failures are unplanned and value-reducing processes. An example of such a product is one whose failure leads to rework or scrapping.

\section{CONCLUSION}

The analysis made within this article has, it is argued, made significant inroads into making the modern definition of quality costs clearer as well as how this concept should be applied in practice. The opportunities for the use of quality costing have also been set out and what action must now be taken to ensure reliable quality costing.

The presentation and application of the theoretical aspects in the area of quality costs in this work represents an important starting point. The presentation of the classical concept of quality costs and its criticisms have led to a use of a modern dichotomy set out and illustrated within this article. It should be more than possible for a seamless transfer of this theoretical knowledge to occur where use of this knowledge can be utilized for practicable purposes.

\section{REFERENCES}

Aniza L., Wang M. H. and Rieger F. (2013) "Development of Quality Cost Model within a Supply Chain Environment”, Applied Mechanics and Materials, 330: 737-742.

ASQC American Society of Quality Control (1971) "Quality Costs - What \& How", Milwaukee, 875.

Bär, K. (1985) Wie Qualitätskosten zum Führungsinstrument werden“, io Management Zeitschrift, 11, 492-494.

Binner, H. (2000) Rechnergestützte Methoden zur prozessorientierten Erfassung qualitäts-bezogener Kosten, in: Hansen, W.; Kamiske, G.: Qualitätsmanagement, Düsseldorf, Symposion Publishing.

Bröckelmann, J. (1995) Entscheidungsorientiertes Qualitätscontrolling: Ein ganzheitliches Instrument der Qualitätssicherung“, Wiesbaden, Gabler Publishing.

Bruhn, M., Georgi, D.(1999) Kosten und Nutzen des Qualitätsmanagements: Grundlagen, Methoden, Fallbeispiele“, München, Carl Hanser Publishing.

Brunner, F. (1988)Steigerung der Effizienz durch Qualitätskostenanalyse“, io Management Zeitschrift, 5: 35-38. 
Brunner, F. (1991) Steigerung der Effizienz durch Qualitätskostenanalyse“, io ManagementZeitschrift, 7/8: 35-38.

Campanella, J. (1999) Principles of Quality Costs: Principles, Implementation and Use“, 3rd Edition, Milwaukee, ASQ Quality Press.

Crosby, P.B. (1986) Qualität ist machbar“, Hamburg, McGraw-Hill.

Danzer, H. (1990) Quality- Denken stärkt die Schlagkraft des Unternehmens“, 1st Edition, Zürich, Verlag industrielle Organisation.

DGQ - Deutsche Gesellschaft für Qualität e.V. (1985) Qualitätskosten: Rahmenempfehlungen zu Ihrer Definition, Erfassung, Beurteilung“،, 5nd Edition, Berlin, Beuth.

Deutsches Institut für Normung e.V. (1995) DIN 55350, Teil 11, Begriffe der Qualitätssicherung und Statistik - Grundbegriffe der Qualitätssicherung“, Berlin, Beuth.

Fischer, T.M. (2000) Qualitätskosten Fischer, T.M. (eds.) Kosten- Controlling: Neue Methoden und Inhalte, 3rd Edition, Stuttgart, Schäffer-Poeschel.

Graf, G. (1998) Nutzenorientierte Qualitätskostenrechnung: Ansätze zur Erfassung und marktorientierten Schätzung von Qualitätskosten auf Basis der Prozesskostenrechnung“, Frankfurt, Berlin, Peter Lang.

Grechenig, T., Bernhart, M., Breiteneder, R. and Kappel, K. (2010) "Softwaretechnik: Mit Fallbeispielen aus realen Entwicklungsprojekten, München, Pearson Studium.

Groocock, J. (1986) "The chain of quality: Market dominance through product superiority", $1^{\text {st }}$ Edition, New York, John Wiley \& Sons.

Hahner, A. (1981) Qualitätskostenrechnung als Informationssystem zur Qualitätslenkung“, München, Hanser.

Harrington, H. (1987) "Poor-Quality Cost: Implementing, Understanding, and Using the Cost of Poor Quality”, Milwaukee, CRC Press.

Herberg, C. (2000) Messung der Effizienz von Total Quality Management: Kennzahlensystem zur Messung der Effizienz von TQM unter besonderer Berücksichtigung der Qualitätskosten“, 2nd Edition, Hamburg, Verlag Dr. Kovac.

Horvath, P. and Urban, G. (1991) “Qualitätscontrolling”, Stuttgart, Schäffer-Poeschel Publication.

Horvath, P. (1997) Qualitätscontrolling“, 2. Edition, Stuttgart, Schäffer-Poeschel Publication.

Kamiske, G. F. (1992) Das untaugliche Mittel der Qualitätskostenrechnung“, Qualität und Zuverlässigkeit, 3: 122-123. 
Kamiske, G.F. and Brauer, J.-P. (2003) Qualitätsmanagement von A bis Z, 4th Edition, München, Hanser.

Kandaouroff, A. (1994) "Qualitätskosten. Eine theoretisch-empirische Analyse", Zeitschrift für Betriebswirtschaft (ZfB), 6:765-786.

Morse, W.J., Roth, H.P. and Poston, K.M. (1987) "Measuring, Planning and Controlling Quality Costs", Massachusetts, Reading.

Reckenfelderbäumer, M. (1994) Entwicklungsstand und Perspektiven der Prozesskostenrechnung“, 1st Edition, Wiesbaden, Gabler.

SAQ - Schweizerische Arbeitsgemeinschaft für Qualität (1985), Rahmenempfehlung zur Organisation der Qualitätssicherung im Unternehmen. Aufbau- und Ablauforganisation, SAQ.

Sasse, A. (2002) Ganzheitliches Qualitätskostenmanagement: Ein Konzept zur wirtschaftlichen Planung, Steuerung und Umsetzung“, 1st Edition, Wiesbaden, Gabler.

Schneidermann, A.-M. (1986) "Optimum Quality Costs and Zero Defects: Are they Contradictory Concepts", Quality Progress, 11: 28-31.

Seghezzi, H.D. and Fries, S. (1995) Zweckmäßige Fehlerkostenrechnung anstatt traditioneller Qualitätskostenrechnung“, Kostenrechnungspraxis (krp), 2:87-91.

Shukla M. K. and Agrawal, P. C. (2012) Impacts of Cost of Poor Quality in Indian Automobile Sector“, International Journal of Engineering Research and Applications, ISSN: 2248 - 9622, 2: 1297-1302.

Spitzner, W. (1988) Qualitätskosten erfassen und bewerten“, Bläsing, J. (eds.) Integriertes Produktions- und Qualitätsmanagement, München, gfmt.

Steinbach, W. (1994) Qualitätsbezogene Kosten“, Masing, W. (eds.) Handbuch Qualitätsmanagement, 3. Edition, München, Gabler.

Steinbeck, H. H. (1995) Das neue Total Quality Management, Qualität aus Kundensicht“, Landsberg, MI.

Tomys, A. (1994) Kostenorientiertes Qualitätsmanagement: ein Beitrag zur Klärung der QualitätKosten-Problematik“, Dissertation, Berlin, Carl Hanser.

Tsai W.-H., Hwang, E. T. Y., Chang J.-C., Chien-Wen L., Sin-Jin L. and Yang C.-H. (2012) "Taxonomy of cost of quality (COQ) across the enterprise resource planning (ERP) implementation phases", African Journal of Business Management, 6(3): 854-864.

Walluch, W. (1980) Die Qualitätskosten: Ein Parameter betrieblicher Entscheidungen“, Graz, Technische Universität Graz, Institut für Betriebswirtschaftslehrer und Betriebssoziologie. 
Wildemann, H. (1992) Kosten- und Leistungsbeurteilung: Kosten- und Leistungsbeurteilung von Qualitätssicherungssystemen“, Zeitschrift für Betriebswirtschaft (ZfB), 7: 761-782.

Wildemann, H. (1995) Kosten und Leistungsbeurteilung im Qualitätskostenmanagement“, Reichmann, T, (eds.) Handbuch Kosten - und Erfolgs-Controlling, München, Vahlen.

Wildemann, H. (1997) Kosten und Leistungsberechnung für präventive Qualitätssicherungssysteme“, Becker, W.; Weber, J. (eds.) Kostenrechnung: Stand und Entwicklungsperspektiven, Wiesbaden, Gabler.

Wilken, C. (1993) Strategische Qualitätsplanung und Qualitätskostenanalysen im Rahmen eines Total Quality Managements“, Heidelberg, Physica.

Wonigeit, J. (1996) Total Quality Management: Grundzüge und Effizienzanalyse“, 2. Edition, Wiesbaden, Deutscher Universitätsverlag.

Wood, D.C. (2013) "Principles of Quality Costs: Financial Measures for Strategic Implementation of Quality Management”, 4. Edition, Milwaukee, Amer Society for Quality. 